DE DE GRUYTER

OPEN

DOI: $10.1515 / \mathrm{aa}-2015-0007$

\title{
Mimesis, interpretation and the human condition
}

\section{Mária Kiššová}

Mária Kiššová currently lectures on Children's literature, British literature, Romanticism and Cultural studies at the Department of English and American Studies at the University of Constantine the Philosopher in Nitra, Slovakia. Her publications include monographs Cultural Encounters in Contemporary Literature (with S. Hevešiová, 2008), Multicultural Awareness - Reading Ethnic Writing (with S. Hevešiová and A. Smiešková, 2008) and Literature and Culture (A. Pokrivčák, et al., 2010) and her reviews and interviews have also been published in the literary journal Ars Aeterna. Her field of interests covers a wide spectrum of interdisciplinary research including literature, art, cultural studies, philosophy, and religion.

\begin{abstract}
One of the most fundamental questions in the discourse on artistic creativity and interpretation is that of mimesis or representation; the relation and the 'tension' between experiential reality on one hand and an artistic construct on the other hand. In the present study, mimesis and the discussion about the connection between the experiential and the imaginary are understood as major characteristics by which man and the human condition are defined. From the context of the visual arts, the study proceeds to literature and, specifically, to an analysis of the novel The Real Life of Sebastian Knight (1941) by Vladimir Nabokov (1899-1977). The main aim of the study is to show the questions of representation and interpretation as part of the universal inquiry about humanity and the human condition.
\end{abstract}

"It is the constant endeavor of the mind to idealize the actual, to accommodate the show of things to the desires of the mind" (Emerson qtd. in Richardson, 1995, p. 255).

1.

"Art is a lie", said Pablo Picasso (1881-1973), who is likely the most influential and revolutionary western artist of the $20^{\text {th }}$ century. Indeed, the essence of artistic mimesis is based on showing/ telling/ representing something which is not 'real' in an experiential sense. 'The lie', however, attempts to point at 'something else', called by Picasso 'the truth'.

The 'art as a lie' idea was studied and expressed in detail in the work of the Belgian surrealist René Magritte (1898-1967). According to Sarah Whitfield, "Magritte's concern with the human condition is the concern of a philosopher but his perception of the visual world is the perception of an artist" (1992, p. 22). While several of Magritte's iconic images deal with the question of artistic representation, the most well-known is probably The 
Treachery of Images (1928-29), popularized in the 1980s by Michel Foucault's text This Is not a Pipe.

Magritte often focuses on the artificiality of art; according to Patricia Almer, he "unmasks the conventional and traditional role of art as asserting presence and permanence, revealing the truth of art as an assertion of absence and impermanence" (2011, p. 6). Besides The Treachery of Images, there is another painting by Magritte relevant to mention in the present study. The work is known as The Human Condition (1933/1935). The 1933 version shows a curtained window with a view of a landscape dominated by a tree and a distant forest. The 1935 version is a somewhat brighter image with an easel, a sea view and a black globe on the floor. In both cases, the artistic artifice is present in the form of an easel with a most realistic painting. Though one clearly sees the frames of the painting within the painting, its juxtaposition with the 'real' view of nature behind it is still striking and surprising and the borders between 'reality' and its representation seem intentionally blurred. Interestingly, the painting called The Human Condition does not portray any human being; the anonymity and absence of the painter, or of any man in the picture, is highly significant. The man is present in the painting only indirectly, in the form of his art.

Magritte described The Human Condition (1933) in the following words: "I placed in front of a window, seen from inside a room, a painting representing exactly that part of the landscape which was hidden from view by the painting. Therefore, the tree represented the real tree situated behind it, outside the room. It existed for the spectator, as it were, simultaneously in his mind, as both inside the room in the painting, and outside in the real landscape. Which is how we see the world: we see it as being outside ourselves even though it is only a mental representation of it that we experience inside ourselves" (Magritte qtd. in Gablik, 1970, p. 184).

Art is based on illusion and deception, says Magritte through these works. At the same time, however, the title of the paintings (The Human Condition) creates richer associations which direct us to interpret them, as Magritte's commentary points out, as expressing not only 'the truth' about artistic representation, but also about seeing and 'interpreting' the world in general. The human condition, the way one perceives and interprets the world is likened to the activity of an artist, the way he observes and represents the outside world. Both kinds of representation (artistic as well as general) are illusions; they are not and never will be the 'real thing' ${ }^{i}$ The ambiguity of human perception is highlighted in Magritte's painting by the presence of curtains, one of his most frequently used images. As Gisela Fischer observes, "When Magritte commented that 'we are surrounded by curtains' he was talking of our 
awareness that we see the world subjectively, as if through a veil of semblances" (2011, p. 45). According to Magritte, "Everything we see hides another thing, we always want to see what is hidden by what we see. There is an interest in that which is hidden and which the visible doesn't show us. This interest can take the form of a quite intense feeling, a sort of conflict, one might say, between the visible that is hidden and the visible that is apparent" (Magritte qtd. in Sylvester, 2010, p. 24). While Magritte's curtains may symbolize separation and the potential to hide and cover, they also suggest man's curiosity and desire to learn, discover and know. Acceptance of the illusory nature of art and human experience has not prevented man from the act of drawing, from drawing the imaginary curtains open, from interpretation and from the search for meaning.

In the text above, two versions of The Human Condition (1933 and 1935) are mentioned. Since these are two slightly different representations of the human condition, a viewer may wonder whether and how the difference may relate to their meaning. Are Magritte's works meant to show two 'versions' of the human condition? Is not the human condition universal? When Magritte was asked about the titles of his paintings, he replied: "The titles are chosen in such a way as to prevent my pictures from being situated in the reassuring region to which people's minds would automatically assign them in order to underestimate their significance. The titles must be an extra protection which will discourage any attempt to reduce pure poetry to a trivial game" (Magritte qtd in Whitfield, 1992, p. 31). ${ }^{\text {ii }}$ Magritte again warns against the lure of 'appearances'; this time represented by words. The title of the work is not important; it is the work which one should focus on. Anything else is obstruction.

Magritte goes even further when he expresses his convictions about the discourse on interpretation in a letter to A. Chauve, dated Sept 30, 1960: "Questions such as "What does this picture mean, what does it represent?" are possible only if one is incapable of seeing a picture in all its truth, only if one automatically understands that a very precise image does not show precisely what it is. It's like believing that the implied meaning (if there is one?) is worth more than the overt meaning. There is no implied meaning in my paintings, despite the confusion that attributes symbolic meaning to my painting. How can anyone enjoy interpreting symbols? They are 'substitutes' that are only useful to a mind that is incapable of knowing the things themselves. A devotee of interpretation cannot see a bird; he only sees it as a symbol. Although this manner of knowing the 'world' may be useful in treating mental illnesses, it would be silly to confuse it with a mind that can be applied to any kind of thinking at all" (qtd. in Torczyner, 1979, p. 70). In the letter, Magritte strongly argues against 
interpretation. His paintings should be 'seen', and 'experienced' not 'interpreted', i.e. discussed in abstract or symbolic terms. It is interesting to observe that interpretation does not even have a 'secondary' status, it is simply rejected. Is such a complete rejection possible?

The prominence of experience and preference for the work of art per se over interpretation are often mentioned in the artistic discourse. In literature, for example, the Anglo-American poet W. H. Auden (1907-1973) comments on the inadequacy and inferiority of an interpretative act: "The poem communicates so much and communicates it so richly and with such delicate qualifications that the thing communicated is mauled and distorted if we attempt to convey it by any vehicle less subtle than that of the poem itself" (qtd in Brooks, 1956, p. 58). While Auden accentuates the natural imperfection of verbal discourse, the Argentine writer Jorge Luis Borges (1899-1986) compares a poem with an apple to illustrate the primacy of the reader's experience: “The taste of the apple (states Berkeley) lies in the contact of the fruit with the palate, not in the fruit itself; in a similar way (I would say) poetry lies in the meeting of poem and reader, not in the lines of symbols printed on pages of a book. What is essential is the aesthetic act, the thrill, the almost physical emotion that comes with each reading" (qtd in Hirsch, 1999, p. 29).

While relevance of the work of art and its experience need not be questioned, to reject any attempt to interpret may be highly problematic. Significantly enough, when we return to Magritte's description of The Human Condition, we discover that while his characterization of the painting consists mainly of its direct description (what one can literally see), he adds his interpretation of the painting. The work, in Magritte's words, depicts "how we see the world: we see it as being outside ourselves even though it is only a mental representation of it that we experience inside ourselves." Magritte seems slightly self-contradictory when on one hand he criticizes interpretation, and on the other hand suggests how to interpret the painting. The will to create and represent seems as natural a part of the human condition as the will to interpret. As Ernst Gombrich asserts, "In looking at a work of art we will always project some additional significance that is not actually given. Indeed we must do so if the work is to come to life for us" (1972, p. 18). In the case of Magritte's The Human Condition, one 'sees', 'experiences', and, naturally, tries to 'understand' and make one's experience 'meaningful'. Since the painting bears the title The Human Condition, it is likely that a viewer would seek possible affinities between the title and the image. Thus, the title does not serve as a veil; on the contrary, it adds further complexity and ambiguity to the act of interpretation. Ben Stoltzfus expresses a similar idea when he writes that Magritte's "paintings can function as independent entities, but their connotations are enhanced by their literary titles and familiarity 
with the written text; and the reader's attention evolves within the space of this iconotext" (Stoltzfus, 2014, p. 57).

2.

A work of imagination is essentially defined by its 'non-factuality'. At the same time, however, as if it were fundamental to create an illusion of 'the real', authors of artistic works - in the following examples the authors of literary works - use various techniques to convince their recipients about the 'reality' of their illusory worlds. Nathaniel Hawthorne's The Scarlet Letter (1850) is one such example. The Custom House, an autobiographical introductory sketch with which Hawthorne's romance begins, convinces the reader about the historical authenticity of the fictional story and explains in detail how the author discovered the material which formed the basis of his work. The narrator even confesses that he is still in possession of the letter A which Hester Prynne wore as a badge of shame.

Another example is Sadegh Hedayat's The Blind Owl (first published in 1937). It is an intoxicating narrative of living corpses, nightmares, mirrors and masks, obsession, shadows, opium, death, poisoned wine, surrealist landscapes of "deserted streets lined with ash-grey houses of strange, geometrical shapes - cubes, prisms, cones - with low, dark windows" (2010, p. 90), recurrent images of flowers of morning glory, old men breaking into "a hollow, grating, gooseflesh-raising peal of laughter" (2010, p. 78). The narrator essays to convince the reader that life and fiction are futile artifices: "Ugh! How many stories about love, copulation, marriage and death already exist, not one of which tells the truth! How sick I am of wellconstructed plots and brilliant writing!" (2010, p. 65)/ "Life is nothing but a fiction, a mere story." (2010, p. 66)/ "Is not life from beginning to end a ludicrous story, an improbable, stupid yarn? Am I not writing my own personal piece of fiction? A story is only an outlet for frustrated aspirations, for aspirations which the storyteller conceives in accordance with a limited stock of spiritual resources inherited from previous generations." (2010, p. 84) However, we also learn: "No, it was not an illusion." (2010, p. 34) What we read is a 'true' story.

In the 1951 novel The End of the Affair, Graham Greene displays a narrative voice of a writer Maurice Bendrix who repeatedly persuades us that his story is 'true' and trustworthy: "It has always seemed to me that in a novel the reader should be allowed to imagine a character in any way he chooses: I do not want to supply him with ready-made illustrations. Now I am betrayed by my own technique, for I do not want any other woman substituted for Sarah, I want the reader to see the one broad forehead and bold mouth, the conformation of 
the skull, but all I can convey is an indeterminate figure turning in the dripping macintosh, saying, 'Yes, Henry? and then 'You?'” (p. 17)/ "If I were writing a novel I would end it here: a novel, I used to think, has to end somewhere, but I'm beginning to believe my realism has been at fault all these years, for nothing in life now ever seems to end" (p. 110). As a result, Greene - through the voice of the fictional author - devises a complex meta-text the effect of which is the emphasis on the artifice and - simultaneously - the lure of authenticity.

The narrator of Michael Frayn's 1989 novel The Trick of It, a literature professor, elaborates on the relevance of the fact - fiction relation in the following way: "I've spent my entire career explaining to students that the inventedness of fiction is its sign and glory. But that doesn't mean it comes from nowhere, made out of nothing. What inventors invent tells you something about the world they inhabit. What fantasists fantasize has some objective correlative, even if it's only in the inside of their own heads. Otherwise our job, yours and mine, is impossible. We have to be able to relate these figments to the figment-tree they came from in some way. There's nothing so wonderfully mysterious about fiction - we all fictionalize" (2000, p. 77).

And finally, a more recent example is Alan Bennett's novella The Uncommon Reader (2007), a story about a British Queen who becomes obsessed with books and reading. A reader simply cannot ignore the association between the fictional Queen and the 'real' image of Elizabeth II and the attraction of the story closely depends on the reader's knowledge of the historical Queen.

It seems evident that one of the most alluring aspects of art is precisely its quality of being 'on the margin'; being embedded in the imaginary realm, and simultaneously relying on the links with the experiential world we are familiar with.

3.

Vladimir Nabokov's novel The Real Life of Sebastian Knight (1941) exemplifies all major points of the above discussion. It is a complex text which deals with the questions of representation, authorship, the connection between real and imaginary worlds, and, last but not least, it is an illustration of artistry which is in this case more important than the artifact.

According to Keith M. Booker, "Nabokov argues throughout his life that literature and reality are entirely separate spheres and that, pace Sartre, fiction should be entirely disengaged from reality. Thus, he claims to see no social or political role for literature at all, beginning a lecture on Madame Bovary during his Cornell days with a typical Nabokovian proclamation that "literature is of no practical value whatsoever" (Lectures 125)" (1994, p. 
99). Vladimir Nabokov was, indeed, convinced that "A work of art has no importance whatever to society. It is only important to the individual, and only the individual reader is important to me" (1964). While the statement rejects the concept of art as socially significant, it stresses the individual reader's experience, similarly to Auden and Borges. Like Magritte, Nabokov is rather skeptical - though not utterly rejecting - in his opinion of art criticism: "Criticism can be instructive in the sense that it gives readers, including the author of the book, some information about the critic's intelligence, or honesty, or both” (1967).

Despite Nabokov's emphasis on reading his fiction as 'pure fiction', the critics still search for 'the real' behind the veil of fictional appearances and The Real Life of Sebastian Knight is not an exception. According to de Vries and Johnson, for instance, "It has often been observed that a number of incidents in The Real Life of Sebastian Knight are distinctly autobiographical. (...) The transition from Russian to English (The Real Life of Sebastian Knight was Nabokov's tenth novel but the first to be written directly in English) was, as Nabokov said, 'exceedingly painful - like learning anew to handle things after losing seven or eight fingers in an explosion (SO 54)'. And the affair with Nina can, as Brian Boyd says, be regarded as 'a stylized alternative continuation of his own recent past', his short-lived relationship with Irina Guadini, which endangered his marriage to Véra, the muse as well as the ancilla of his art. And the death of his father, which might be regarded as one of the most incisive occurrences in his life, has often inspired Nabokov to think about the hereafter and about how he could have contact with it" (2006, p. 40). The American scholar Svein Arber, in the comments on the central character of The Real Life of Sebastian Knight points out that, "Not only are Nabokov and Knight similar writers, they also began their lives in a like manner, for both the "real" person and his fictional counterpart were born in St. Petersburg in 1899, left Russia after the Revolution of 1917, and went to England to study at Cambridge" (2013, p. 21). Arber believes "that Nabokov was haunted throughout his life by nagging memories of that fateful night [when his father was killed, MK], and that he coped with his ongoing despair by inserting masked allusions to his father's assassination throughout his fiction" (2013, p. 23).

Vladimir Nabokov reflects on the fictional and the real in his autobiographical text Speak, Memory (1951) which details Nabokov's past from his early childhood. The memoir demonstrates that while Nabokov's "imagination is rooted in memory" (Boyd, 2011, p. 51), the real and the fictional are always two distinct realms. The creation of a fictional character based on a real person clearly suggests something definite. It is a one-way process in which an aspect once made fictional enters the realm of no return. Nabokov explains: "I have often 
noticed that after I had bestowed on the characters of my novels some treasured item of my past, it would pine away in the artificial world where I had abruptly placed it. Although it lingered on in my mind, its personal warmth, its retrospective appeal had gone and, presently, it became more closely identified with my novel than with my former self, where it had seemed to be so safe from the intrusion of the artist" (1989, p. 95). It is interesting to observe how vividly and intensely the distinction between the real and the fictional is felt by the author. A real object or person undergoes a fundamental change, a referential frame of "the real' disappears and the image obtains a completely different 'purpose', structural and semantic meaning in the newly created imaginary work. For that reason, the discussion about the former context and the 'real' frame of reference is irrelevant. The distinction between 'the real' and 'the fictional' enables an artist to peruse the images from the experiential world freely for their own artistic aims.

I would like to present three examples which document Nabokov's transformation of the real to the fictional.

The first example is the character of Mademoiselle, the Swiss governess who stayed with the Nabokov family from December 1905. In Speak, Memory, Nabokov admits how difficult is to revive her 'real' (read: historic) image after she had already been fictionalized. He struggles to 'get her back' from fiction to reality: "The man in me revolts against the fictionist, and here is my desperate attempt to save what is left of poor Mademoiselle" (1989, p. 95). The memories slowly return and an image of historic Mademoiselle appears. We learn, for instance, among other interesting details, that "[h]er Russian vocabulary consisted, [...] of one short word, the same solitary word that years later she was to take back to Switzerland" (1989, p. 98). Nabokov further describes how several years after Mademoiselle had left the family, he visited her in Lausanne. She was "[s]touter than ever, quite gray and almost totally deaf, she welcomed me with a tumultuous outburst of affection" (1989, p. 115). In Lausanne, Nabokov also "found in the neighborhood quite a colony of such old Swiss governesses. Huddled together in a constant seething of competitive reminiscences, they formed a small island in an environment that had grown alien to them" (1989, p. 115). The memory of the old ladies eventually becomes part of Nabokov's thoughts about the past, homeland and the sense of belonging. Himself an émigré, he must have understood how "[o]ne is always at home in one's past, which partly explains those pathetic ladies' posthumous love for a remote and, to be perfectly frank, rather appalling country, which they never had really known and in which none of them had been very content" (1989, p. 116). 
The character of Mademoiselle appears in The Real Life of Sebastian Knight, too. In this case, she is one of several people whom the narrator $\mathrm{V}$. interviews to collect information for his biography of Sebastian Knight: "I found Mademoiselle very deaf and grey, but as voluble as ever, and after the first effusive embraces she started to recall little facts of my childhood which were either hopelessly distorted, or so foreign to my memory that I doubted their past reality" (2011, p. 16). While in V.'s description of the visit to Mademoiselle some aspects of the historic person may surface; it would be a fallacy, however, to mistake the fictional for the real. The 'purpose' of the character in the novel is different. She is changed into an artistic creation, one of the unreliable witnesses to Sebastian Knight's childhood. The old Swiss governesses also appear in the novel. In the narrative, they thematically become part of the artistic discourse on migration and displacement: "Their tragedy lay in the fact that during those years spent in a foreign country they had kept absolutely immune to its influence (even to the extent of not learning the simplest Russian words); somewhat hostile to their surroundings - how often have I heard Mademoiselle bemoan her exile, complain of being slighted and misunderstood, and yearn for her fair native land; but when these poor wandering souls came home, they found themselves complete strangers in a changed country, so that by a queer trick of sentiment - Russia (which to them had really been an unknown abyss, remotely rumbling beyond a lamplit corner of a stuffy black room with family photographs in mother-of-pearl frames and a water-colour view of Chillon castle), unknown Russia now took on the aspect of a lost paradise, a vast, vague but retrospectively friendly place, peopled with wistful fancies" (2011, p. 15-16).

The second image is of Nabokov's mother. In Speak, Memory, we find a portrait-like animated description of Elena Ivanovna: "With great clarity, I can see her sitting at a table and serenely considering the laid-out cards of a game of solitaire: she leans on her left elbow and presses to her cheek the free thumb of her left hand, in which, close to her mouth, she holds a cigarette, while her right hand stretches toward the next card. The double gleam of her fourth finger is two marriage rings - her own and my father's, which, being too large for her, is fastened to hers by a bit of black thread" $(1989$, p. 50). There is a striking similarity between the previous depiction and an image of V.'s mother from The Real Life of Sebastian Knight: "I remember the way my mother sat, with her hands in her lap twirling my father's wedding ring (as she usually did when inactive) which she wore on the same finger as her own and which was so large that she had tied it to her own with black thread" (2011, p. 21). The similarity is indeed noticeable, but as in the previous case, V.'s mother has a different 'history', her twirling of a husband's ring fastened by black thread is just one of the images by 
which she is created. The image is freed from its original context and becomes 'meaningful' only if interpreted in the context of the novel.

The third example is Nabokov's brother Sergey. In Speak, Memory, Nabokov confesses how difficult it is for him to recall Sergey and to bridge the distance which had always existed between them. Interestingly, Nabokov directly mentions The Real Life of Sebastian Knight when he describes his frustration about Sergey: "For various reasons I find it inordinately hard to speak about my other brother. That twisted quest for Sebastian Knight (1940), with its gloriettes and self-mate combinations, is really nothing in comparison to the task I balked in the first version of this memoir and am faced with now" (1989, p. 257). The failure to recover the image of a brother (a half-brother actually) is a central theme of The Real Life of Sebastian Knight. The narrator acknowledges: "Sebastian's image does not appear as part of my boyhood, thus subject to endless selection and development, nor does it appear as a succession of familiar visions, but it comes to me in a few bright patches, as if he were not a constant member of our family, but some erratic visitor passing across a lighted room and then for a long interval fading into the night" (2011, p. 12). Though it is tempting to see V. standing for Vladimir and Sergey for Sebastian; this 'reading' would reduce and lessen the interpretative potential of the novel. While the parallels may offer some input for interpretation, Nabokov's poetics shows a strict preference for non-biographical and nonhistorical reading. In The Real Life of Sebastian Knight, he is a craftsman, not a historian.

4.

Vladimir Nabokov's The Real Life of Sebastian Knight is 'a biography' of a (fictional) author Sebastian Knight (1899-1936) written and narrated by his half-brother V. According to V.'s narrative, this is not the first attempt to map Knight's life. The first biography, with the Shakespearean title The Tragedy of Sebastian Knight was written soon after Knight's death by his secretary Mr. Goodman whose qualities as a person as well as a biographer V. vehemently and repeatedly questions: "In his slapdash and very misleading book, Mr Goodman paints in a few ill-chosen sentences a ridiculously wrong picture of Sebastian Knight's childhood" (2011, p. 10)/ "this solemn biographer is out of tune with his hero at every point of the story" (2011, p. 14). We learn that before he started his personal search for the details about his late halfbrother, V. had not known about Goodman's work and seemed to have initiated the project merely as a token of personal admiration for Sebastian Knight's work. As V.'s quest progresses, however, a reader starts to be suspicious and skeptical about V.'s motives. The narrative emotionally intensifies and V.'s obsession with his subject grows, eventually ending 
in a quasi-mystical moment when the borders between the biographer and his subject utterly disappear. It is important to realize that 'intensification' of V.'s emotions is an effective artistic strategy used by Nabokov. The events at the end of the text (V.'s journey to meet the dying Sebastian) had actually taken place before V.'s quest was initiated. The last part of the novel suggests an alternative motive for V.'s quest. He might have started his project for a very subjective, even egotistical reason to learn 'the mystery' and 'hidden message' which he strongly believes Sebastian intended to share.

V. and Sebastian had never been close. It was only shortly before his death that V. got a message that Sebastian wanted to meet him. V. interprets the message as the urgent call of a person longing to share his 'ultimate wisdom'. V. trusts this interpretation of Sebastian's call more and more until he becomes obsessed with the desire to meet his half-brother before he dies: "I knew he was calling me and saying something very important - and promising to tell me something more important still, if only I came to the corner where he sat or lay" (2011, p. 167)/ "Never in my life had I wanted a thing as fiercely as I wanted to find Sebastian alive to bend over him and catch the words he would say. His last book, my recent dream, the mysteriousness of his letter - all made me firmly believe that extraordinary revelation would come from his lips. If I found them still moving. If I were not too late” (2011, p. 171). The novel ends with a gripping description of V. standing next to a bed where he is convinced Sebastian is sleeping. Tragically, V. finds out that he is too late and he will never personally learn the secret from his late brother.

In the following, I would like to analyse The Real Life of Sebastian Knight with a detailed focus on the concept of representation; specifically on the relation between 'reality' and 'fiction' within the fictional work. I will explore how this metafictional narrative examines the tensions between the experiential and the imaginary and, as a result, addresses an important issue by which the human condition is defined.

According to Svein Arber, "Any reader attempting to unravel the mysteries concealed in The Real Life of Sebastian Knight will almost surely ponder the author's use of the word "real" in the title. For, as a number of critics have pointed out, Nabokov is well aware that it is absurd to suggest that any narrative, however carefully wrought, can put us in touch with reality" (2013, p. 16). David Shields similarly notes that "the novel title assumes a sophistication beyond us and therefore an implicit antagonism toward us, for certainly readers who approach The Real Life of Sebastian Knight with the expectation that they're going to get the "real life" of Sebastian Knight are deceived" (2003, p. 18). Would it be more apt to name the novel 'The Fictional Life of Sebastian Knight' or even 'The Life of Sebastian Knight'? 
The title of the book is part of Nabokov's artistic deception and it serves this purpose very well. The adjective 'real' provides the reader with an essential clue to the text. Its beauty and power depend on the reader's suspension of disbelief. We open the book and willingly let the novelist manipulate us. The novel 'pretends' to be a biography and we accept the pretense as a natural part of artistic communication. We are well aware that V. and Sebastian are 'not real'; but, for the (fictional) time being, they 'are'. In his introduction to the novel, Michael Dirda asks: "is the "real life" of Sebastian Knight his "afterlife"?" (2008, p. xviii) The answer to that question is naturally subjective. If the novel itself is indeed considered a story with 'a secret', inventive readers may come up with original answers. They may even propose a connection between the first ('Sebastian Knight') and the last word ('knows') of the text as a possible solution to the quest for the 'hidden word(s)' which Sebastian might have intended to share. As the use of modal verbs imply, in Nabokov's world everything is hypothetical, nothing is certain, all is artifice.

In the novel, Nabokov intentionally and frequently devises situations which evoke an ambiguity between 'the real' and 'the fictional' (within the fictional world), especially as some characters and events in V.'s quest mirror the situations and characters from Sebastian's fiction. According to Brian Boyd, “As we follow V.'s quest for Sebastian's lethal last love and as we draw closer to Sebastian's death, we sense more and more sharply that Sebastian's novels somehow anticipate V.'s search or that the search somehow reenacts the novels. We seem about to resolve this crescendo of echoes as the book itself swells with the promise of an all-deciding disclosure from the dying Sebastian - and that in turn mimics the pattern of Sebastian's last novel. Listening to the sleeping patient breathe, V. experiences a profound spiritual communion that courses through his whole being. But it all turns out to be a ghastly mistake" (1990, p. 498). David Rutledge also observes that fiction mirroring fiction plays an important role in the novel, particularly in V.'s search for Sebastian's last word: “The entire structure of The Real Life of Sebastian Knight embodies this metaphysical idea of the unspoken final word, that word which could encapsulate a "real life". There is no concluding word, but there is the idea of a concluding word. (This revelation of an all-encompassing, allmeaningful final word is also the method of the conclusion of Sebastian Knight's final book, The Doubtful Asphodel (176-178). There, too, the word is suggested yet never revealed.)" (2011, p. 166).

Obviously, the effect of the 'fictional reality' mirroring 'fiction' does not add plausibility of V.'s narrative. The result is a paradox. However willing readers may be to yield 
to the belief of reading 'a biography'; their suspension of disbelief is constantly unsettled and attention is directed to see the text as a crafted artifice.

As the process of layering the two fictional worlds enfolds, readers question both. They may even slightly naively ask: Is anything at all 'meant' to be 'real'? Such a question may sound absurd in a discussion about fiction; nevertheless, it is legitimate. One of the basic characteristics of fiction is the author's creation of a fictional world based on specific premises. If 'the rules of the game' are constantly questioned, it ceases to be clear whether the text offers more than the focus on artifice and incredulity itself.

To better understand the principles employed in The Real Life of Sebastian Knight, it may be useful to return to his Speak, Memory in which Nabokov explains what he believes to be the true art of autobiographical writing. Nabokov points out that the artistry of life writing is based on the author's ability to discern and follow the patterns of recurrent images, situations and motifs in one's life. The case he writes about starts with Nabokov's memory of a family friend, General Kuropatkin. During the visit, the General displayed a set of matches to imitate the sea for little Vladimir. The game was interrupted as Kuropatkin had to leave suddenly, "the loose matches jumping up on the divan as his weight left it" (1989, p. 27). Nabokov further details how the image of scattered matches had its "special sequel fifteen years later" (1989, p. 27) when Vladimir's father met the impoverished General "who looked like a grey-bearded peasant in his sheepskin coat" (1989, p. 27). When Kuropatkin asked Nabokov's father for a light, they recognized each other. The matches reappeared. Nabokov further explains how the analogies and patterns reflected from hindsight give one's life specific beauty and attractiveness: "What pleases me is the evolution of the match theme: those magic ones he had shown me had been trifled and mislaid, and his armies had also vanished, and everything had fallen through, like my toy trains that, in the winter of 1904-05, in Wiesbaden, I tried to run over the frozen puddles in the grounds of the Hotel Oranien. The following of such thematic designs through one's life should be, I think, the true purpose of autobiography" (1989, p. 27).

In the passage Nabokov assesses the quality of life writing - and indirectly of life itself - by the criterion which is applicable to the criticism of a work of art; namely, that beauty lies in perfected forms, patterns and proportions ${ }^{\mathrm{iii}}$. The profusion of similarities in the fictional worlds of The Real Life of Sebastian Knight (the supposedly 'real' world of Sebastian Knight and fictional universes created by him) may be seen as an attempt to compose a perfect lifewriting in which the patterns would appear everywhere, discernible not only in one reality but emerging in all possible 'realities'. 
The chronology of Sebastian Knight's life as narrated by V. consists of these major 'real' events:

\begin{tabular}{|l|l|}
\hline 31.12 .1899 & Sebastian Knight is born \\
\hline \multirow{2}{*}{1905} & Sebastian's father marries again \\
\cline { 2 - 2 } & V. is born \\
\hline Summer 1909 & Virginia Knight (Sebastian's mother) visits in Paris \\
\hline January 1913 & Virginia Knight dies in Roquebrune \\
\hline 1916 & Father's duel with Palchin \\
\hline 1917 & Sebastian's first love; Natasha Rosanov \\
\hline November 1918 & Sebastian's adventure with Alexis Pan \\
\hline 1919 & Fleeing from Russia to Finland \\
\hline $1919-22$ & Sebastian in England \\
\hline 1922 & Sebastian's Cambridge years \\
\hline & Sebastian's visit to Roquebrune (after his stay at Cambridge) \\
\cline { 2 - 2 } & Mother tells V. about the past \\
\cline { 2 - 2 } & Mother dies \\
\hline Spring 1924 & Sebastian meets Clare Bishop at a party in London \\
\hline November or December & Sebastian and V. meet in Paris \\
\hline 1924 & \\
\hline March 1925 & The Prismatic Bezel published \\
\hline $1925-27$ & Sebastian is writing Success \\
\hline Summer 1926 & Treatment in Germany \\
\hline 1927 or 1928 & Miss Pratt notices Sebastian's first attack of illness \\
\hline June 1929 & Sebastian's stay at Blauberg \\
\hline Sept. 1929- January 1930 & Sebastian is missing \\
\hline $1930-1934$ & Mr. Goodman works as a secretary for Sebastian \\
\hline 1932 & A collection of short stories The Funny Mountain is published \\
\hline 1933 & Sebastian is painted by Roy Carswell \\
\hline Spring 1935 & Doubtful Asphodel published \\
\hline August 1935 & Sebastian is seriously ill \\
\hline Middle of January 1936 & Sebastian dies \\
\hline two months after S's death & V. starts writing Sebastian's biography \\
\hline
\end{tabular}

At first sight the novel follows the expected and standard conventions of a biography. The book starts in a most traditional way, with the date and birthplace of Sebastian Knight: "Sebastian Knight was born on the thirty-first of December 1899, in the former capital of my country" $(2011$, p. 1). The story ends with his death. The chronology of his life (see the table above) can also be sufficiently constructed.

Nonetheless, the previous discussion suggested that the account of Sebastian's life is 'problematized' through the presence and interference of the biographer. V. already appears indirectly in the first sentence, when St Petersburg is referred to as "the former capital of my country" (2011, p. 1, underlined by MK). Soon after, V. enters the scene again and discloses his relation to Sebastian: "I have not been able to obtain a picture of the house where 
Sebastian was born, but I know it well, for I was born there myself, some six years later. We had the same father: he had married again, soon after divorcing Sebastian's mother" (2011, p. 2). V. is present in the text as a character but even more apparently as a narrative voice distinguished by noticeable poetic ambitions. We become aware from the very first page that V. does not follow the role of a 'detached' biographer. Despite his claims: "I want to be scientifically precise" (2011, p. 55) and "I shall not attempt to describe Sebastian's boyhood with anything like the methodical continuity which I would have normally achieved had Sebastian been a character of fiction" (2011, p. 15), V. is more convincing as a poet than a non-fiction writer.

The first informant mentioned in the book whom V. meets is a Russian émigré living in Paris. V. accepts her wish to remain anonymous, but he soon changes his mind: "On second thought I cannot see any real necessity of complying with her anonymity. That she will ever read this book seems wildly improbable. Her name was and is Olga Olegovna Orlova - an egg-like alliteration which it would have been a pity to withhold" (2011, p. 1). Olga Olegovna Orlova does not contribute much information to V.'s quest. In fact, the only thing V. learns from her is what the weather was like on the day Sebastian Knight was born. V. mentions this arbitrary, even redundant detail which actually provides him with an excuse to introduce the informant's name. Could it not be the real reason why he decided to mention the information about the weather at all? The remarkable assonance and poetic quality of Orlova's name seemed to have been too valuable (in aesthetic terms) to miss. However, her unsatisfactory and 'dry' report of weather needed improvement and V. supplies his own description of the place. It is neither 'realistic' nor 'information-packed'. Contrary to the factual precision and exactness of biographical writing, $\mathrm{V}$ creates a 17-line impressionistic sketch of St Petersburg, lyricisms of which evoke Virginia Woolf's meditative writings: "the pure luxury of cloudless sky designed not to warm the flesh, but solely to please the eye; the sheen of sledge-cuts on the hard-beaten snow of spacious streets with a tawny tinge about the middle tracks due to a rich mixture of horse-dung; the brightly coloured bunch of toy-balloons hawked by an aproned pedlar; the soft curve of a cupola, its gold dimmed by the bloom of powdery frost; the birch trees in the public gardens, every tiniest twig outlined in white; the rasp and tinkle of winter traffic...” (2011, p. 1-2).

Many other examples which show the distinctive lyricism, subjectivism and emotionalism of V.'s style may be quoted. For instance; in the narrator's account of Sebastian's visit to V. and his mother in Paris, he describes how at the end of the visit, not much was left to say and V. feels an awkward silence which descended on them: "Suddenly 
for no earthly reason I felt immensely sorry for him and longed to say something real, something with wings and a heart but the birds I wanted settled on my shoulders and head only later when I was alone and not in need of words" (2011, p. 25). Another example is related to V.'s visit to Blauberg where he meets a hotel manager refusing to speak to the biographer (whose quest thus seemed to come to a dead end): "The stream of the biography on which I longed so to start, was, at one of its last bends, enshrouded in pale mist; like the valley I was contemplating. Could I leave it thus and write the book all the same? A book with a blind spot. An unfinished picture - uncoloured limbs of the martyr with the arrows in his side" (2011, p. 109). The next opportunity to use a highly subjective tone comes when V. describes how his quest has turned surreal, magical, dream-like, as if guided by its own rhythm: "my quest had developed its own magic and logic and though I sometimes cannot help believing that it had gradually grown into a dream, that quest, using the pattern of reality for the weaving of its own fancies, I am forced to recognize that I was being led right, and that in striving to render Sebastian's life I must now follow the same rhythmical interlacements" (2011, p. 120).

One of the striking examples of mirroring in the novel is the resemblance of the styles used by V. as a biographer and Sebastian as a fiction writer. A reader learns about the latter from many quotations used by V. to illustrate Knight's life and personality and to fill the many gaps in Sebastian's story. Regarding his own style, V. writes: "I cannot even copy his manner because the manner of his prose was the manner of his thinking and that was a dazzling succession of gaps; and you cannot ape a gap because you are abound to fill it in somehow or other - and blot it out in the process" $(2011$, p. 28). V. is an extremely ambitious and self-assured biographer. As the previous quote shows, he is rather self-confident and takes for granted that he knows not only what Sebastian experienced (he learns that from his informants) but also what Sebastian thought and how he felt. The following quote shows the way in which V. ascribes emotions and thoughts to his subject: "And as he entered the stately gloom of Great Court with gowned shadows passing in the mist and the porter's bowler hat bobbing in front of him, Sebastian felt that he somehow recognized every sensation, the wholesome reek of damp turf, the ancient sonority of stone slabs under heel, the blurred outlines of dark walls overhead - everything. That special feeling of elation probably endured for quite a long time, but there was something else intermingled with it, and later on predominant. Sebastian in spite of himself realized with perhaps a kind of helpless amazement (for he had expected more from England than she could do for him) that no matter how wisely and sweetly his new surroundings played up to his old dreams, he himself, or rather still the 
most precious part of himself, would remain as hopelessly alone as it had always been. The keynote of Sebastian's life was solitude and the kindlier fate tried to make him feel at home by counterfeiting admirably the things he thought he wanted, the more he was aware of his inability to fit into the picture - into any kind of picture" (2011, p. 35-36, underlined by MK). As the narrative unfolds, there are more and more gaps in Knight's life which need be filled. For example, when V. describes Sebastian's love affair with Clare Bishop, he uses the same strategy, interpolates his assumptions extensively and offers us a story which is not Sebastian's at all, but V.'s subjective invention: "They must have had a glorious time together, those two. And it is hard to believe that the warmth, the tenderness, the beauty of it has not been gathered, and it is not treasured somewhere, somehow, by some immortal witness of mortal life. They must have been seen wandering in Kew Gardens, or Richmond Park (personally I have never been there but the names attract me), or eating ham and eggs at some pretty inn in their summer rambles in the country, or reading on the vast divan in Sebastian's study with the fire cheerfully burning and an English Christmas already filling the air with faintly spicy smells on a background of lavender and leather" (2011, p. 75, underlined by MK). V. even suggests in a self-critical tone that the quality of his writing depends on capturing the thoughts of Sebastian: "If here and there I have not captured at least the shadow of his thought, or if now and then unconscious cerebration has not led me to take the right turn in his private labyrinth, then my book is a clumsy failure" (2011, p. 161).

V. justifies his role of an 'omniscient' biographer on the basis of 'psychological affinities' that he believes exist between him and his subject: "we did possess certain psychological affinities" (2011, p. 28). V. openly talks about "inner knowledge of his character" (2011, p. 26) and is proud to state that "when I imagined actions of his which I heard of only after his death, I knew for certain that in such or such a case I should have acted just as he had" (2011, p. 26).

V.'s obsession with Sebastian is almost pathological, a result of which is that any aspect of his narrative can be questioned. As Jonathan Sisson observes, the integrity and reliability of V. are highly disputable: "possibility that V. is not Sebastian's half-brother can be neither proven nor disproven, and it shimmers in the reader's mind throughout the novel, now brightly, now dimly, enhancing the poignancy of V.'s yearning to live in Sebastian's soul" (2014, p. 635). The process of merging culminates at the end when V. identifies with Sebastian completely: “try as I may, I cannot get out of my part: Sebastian's mask clings to my face, the likeness will not be washed off. I am Sebastian, or Sebastian is I, or perhaps we both are someone whom neither of us knows" (2011, p. 181). It is important to realize, 
however, that chronologically, the 'complete' identification of V. with Sebastian had taken place before he initiated the quest. Thus, at the end we learn an important key which enables us to understand all striking similarities and resemblances between the biographer and his subject.

Significantly enough, despite V.'s constant attempt to fill the gaps in Sebastian's life either by the quotes from his fiction or by his made-up accounts of Knight's emotional life, Sebastian remains an elusive subject, and not only for the biographer. His mother, for instance, admits that she never understood Sebastian's 'adventure' with Alexis Pan in 1917: "Why he had joined in that ludicrous show and what in fact had led him to pal with that grotesque couple remained mystery" (2011, p. 23) and she further confesses: "I've always felt (...) that I never really knew Sebastian" (2011, p. 24), "he will always remain an enigma" (2011, p. 24).

It is difficult to say whether V.'s quest has been successful or not, for significant gaps in the narrative remain in the story. One of V's great failures is, for example, that he never manages to interview who is likely the most important person in Sebastian's life, Clare Bishop. Moreover, he never learns the vital utterance which might have been the supreme motivation for the quest.

\section{5.}

John Keats once wrote that “A man's life of any worth is a continuous allegory and very few eyes can see the mystery" (qtd. in Sherry, 2004, p. xviii). The elusiveness of the human being, the impossibility to capture one's life regardless of the effort is an important theme which underlies The Real Life of Sebastian Knight and which is an important argument for seeing the novel as universally appealing. Jonathan Sisson describes the novel as "an exquisite ghost story" (2014, p. 637), haunted by the presence of the ever escaping Sebastian. It is indeed so. Where is 'the truth' about the person to be found? In the reports of his relatives and friends, or in his fictions, or one should simply 'invent' and 'shape' another man's character according to one's interpretation? As V. meditates: "The man is dead and we do not know. The asphodel on the other shore is as doubtful as ever. We hold a dead book in our hands. Or are we mistaken? I sometimes feel when I turn the pages of Sebastian's masterpiece that the 'absolute solution' is there, somewhere, concealed in some passage I have read too hastily, or that it is intertwined with other words whose familiar guise deceived me. I don't know any other book that gives one this special sensation, and perhaps this was the author's special intention" (2011, p. 158). What readers end up with after finishing the novel is an 
intricate artifice which reminds them - like Magritte's The Human Condition - that the perception of the world is conveyed exclusively through a web of representations.

While the mentioned painting reflects on representation as a fundamental aspect of human condition per se, Magritte's work The Submissive Reader (1928) is an engaging painting about the act of reading and interpretation. It is an image of a woman in a blue Tshirt reclining on a blue wall. She is utterly captivated, even baffled and shocked by the book she is holding in her hands. The painting illustrates a 'model' act of reading: a reader who is so engrossed by the text that she completely ignores the outside world. According to Brian Boyd, "Literature aims to understand human minds only to the degree it seeks to move human minds. It may move readers' minds, in part, by showing with new accuracy or vividness, or at least with fresh particulars, how fictional minds move, and by showing in new ways how freely readers' minds can move, given the right prompts" (2011, p. 55). The young woman in Magritte's image is definitely moved by the book, and we wonder what might be the content that is so appealing? However, this Magritte does not answer. The 'meaningful silence', the possibility for a reader's input and participation, is one of the most engaging and intriguing aspects of artistic representation and interpretation. The English artist David Hockney said that "A good painting has real ambiguities which you never get to grips with, and that's what is so tantalizing" (2009, p. 20). In a similar way, Stanley Kubrick expressed his unwillingness to provide the viewers the 'key' to his 2001: A Space Odyssey: "How could we possibly appreciate the Mona Lisa if Leonardo had written at the bottom of the canvas: 'The lady is smiling because she is hiding a secret from her lover! This would shackle the viewer to reality, and I don't want this to happen to 2001" (qtd. in Agel, 1970, p. 93).

Art is created to represent but, simultaneously, artistic representation implies encoding, something that is hidden behind artistic 'appearances' and which eventually enables the act of interpretation. This 'interpretative potential' is aptly described by V. in The Real Life of Sebastian Knight: "We feel that we are on the brink of some absolute truth, dazzling in its splendor and at the same time almost homely in its perfect simplicity. By an incredible feat of suggestive wording, the author makes us believe that he knows the truth about death and that he is going to tell it. In a moment or two, at the end of this sentence, in the middle of the next, or perhaps a little further still, we shall learn something that will change all our concepts, as if we discovered that by moving our arms in some simple, but never yet attempted manner, we could fly" (2011, p. 156). The potential naturally contains a paradox, like Sebastian's secret which might have never 'really' existed. 
It is possible to understand the act of reading as the search for 'the other human being' in art. As an activity which bridges the experiential with the fictional, it is natural that artistic production is often self-referential, pointing to its ambiguous status as artifice and experience. As a result, the meta-referential discourse unavoidably also engages the role of the author ${ }^{\text {iv }}$. I understand the search for an author (whether 'real' or 'fictional' - as in the analysed novel) as part of the universal human quest for 'the reality' which is unreachable; yet its illusory effect prevents us from giving up the exploration. As a result, one of the functions of art (and art criticism) is to study the limits and ambivalences of representation and thus to point at the intricacies of the human condition. In the case of The Real Life of Sebastian Knight, V.'s attempt to produce a biography ends up as a masterfully constructed fictional narrative. Naturally, the admiration we feel is primarily for the skills of Vladimir Nabokov, the 'real' author of the text; at the same time, however, we willingly become submissive readers and simply enjoy the artifice.

\section{Endnotes:}

${ }^{i}$ Cf. Thomas Bernhard's comment on the unbridgeable gap between the experience and its verbal expression: "Whatever you write it's always a catastrophe. That's the depressing thing about the fate of a writer. One can never put on paper what one thought of or imagined. That gets lost when it is put onto paper. All you deliver is a bad, ridiculous copy of what you had imagined. Basically, one cannot communicate all that. No one ever managed to do so" (1986). ii We know that how Magritte named his works was usually arbitrary and accidental; he even asked his friends to name the paintings. Magritte also had no definite plan or pattern when it came to his exhibitions. For instance, Harry Torczyner mentions that "The order in which his paintings were hung in an exhibition was unimportant to him; only the works counted, not their dates" (1979, p. 14).

iii Cf. Peter Zlatoš's assumption that "the problem of artistic mimesis stands for the problem of the artwork's morphology in the widest possible sense of the word" $(2002$, p. 70).

iv The opinions of authors themselves regarding the relation between the creator, his artifice and its biographical readings significantly differ. For instance, the poet W. H. Auden was an outspoken critic of biographies: "Biographies of writers, whether written by others or themselves, are always superfluous and usually in bad taste. A writer is a maker, not a man of action" (1982, p. viii). On the other hand, John Fowles said that "What is irreplaceable in any object of art is never, in the final analysis, its technique or craft, but the personality of the artist, the expression of his or her unique and individual feeling" (2000, p. 46).

\section{Works cited:}

Agel, J. (ed.). 1970. The Making of Kubrick's 2001. New York: Signet.

Arber, S. 2013. Nabokov's Personal Demons in the Real Life of Sebastian Knight and Pale Fire. Northampton: Big Tree Books.

Almer, P. 2011. ABSENCE. In Grunenberg, Christoph (ed.). Rene Magritte A to Z. London: Tate Publishing, p. 6.

Auden, W. H. 1982. A Certain World: A Commonplace Book. London: Faber and Faber. 
Bennett, A. 2008. The Uncommon Reader. London: Faber and Faber.

Bernhard, T. "From One Catastrophe to the Next." Interview with Asta Scheib. 1986. [Accessed 2015-08-16]. Available at:

$<$ http://thomasbernhard.org/interviews/1986intas.shtml>.

Booker, K. M. 1994. Vargas Llosa Among the Postmodernists. University Press of Florida.

Boyd, B. 2011. The Psychologist. Vladimir Nabokov's understanding of human nature anticipated the advances in psychology since his day. In American Scholar, Autumn 2011, Vol. 80, Issue 4, p. 47-55.

Boyd, B. 1990. Vladimir Nabokov: The Russian Years. Princeton: Princeton University Press.

Boyd, B. 1991. Vladimir Nabokov: The American Years. Princeton: Princeton University Press.

Brooks, C. 1956. The Well Wrought Urn: Studies in the Structure of Poetry. Boston: Mariner Books.

Bruffee, K. A. 1973. Form and Meaning in Nabokov's Real Life of Sebastian Knight. An Example of Elegiac Romance. In Modern Language Quarterly, June 1973, p. 180-190.

Connoly, J. W. From Biography to Autobiography and Back: The Fictionalization of The Narrated Self in The Real Life of Sebastian Knight. In Cycnos, Volume 10, Issue 1, 2008. [Accessed 2015-08-16]. Available at <http://revel.unice.fr/cycnos/index.html?id=1286>.

Dirda, M. 2008. Introduction. In Nabokov, V. The Real Life of Sebastian Knight. New York: New Directions Publishing.

Fischer, G. 2011. CURTAIN. In Grunenberg, C. (ed.). Rene Magritte A to Z. London: Tate Publishing, p. 45.

Fowles, J. 2000. The Tree. London: Vintage.

Frayn, M. 2000. The Trick of It. London: Faber and Faber.

Gablik, S. 1970. Magritte. London: Thames and Hudson.

Gold, H. 1967. Vladimir Nabokov, The Art of Fiction. In The Paris Review, No. 41. [Accessed 2015-08-16]. Available at $<\mathrm{http}$ ://www.theparisreview.org/interviews/4310/the-artof-fiction-no-40-vladimir-nabokov>.

Gombrich, E. H. 1972. Symbolic Images. London: Phaidon Press.

Greene, G. The End of the Affair. London: Media Circus Productions.

Hart, B. D. 2014. Nabokov's Supernatural Secret. In First Things: A Monthly Journal of Religion and Public Life, March 2014, p. 35-40.

Hedayat, S. 2010. The Blind Owl. New York: Grove Press.

Hirsch, E. 1990. How to Read a Poem: And Fall in Love with Poetry. San Diego, New York and London: A Harvest Book.

Hockney, D. 2009. Hockney on Art: Conversations with Paul Joyce. New York: Little, Brown Book Group.

Malíčková, M. 2008. Hra(nie) len ako estetický fenomén. Nitra: Univerzita Konštantína Filozofa.

Nabokov, V. 2011. The Real Life of Sebastian Knight. London: Penguin Books.

Nabokov, V. 1989. Speak, Memory. New York: Vintage Books.

Popova, M. 1969. Vladimir Nabokov on Literature and Life. 1969. [Accessed 2015-08-16]. Available at <http://www.brainpickings.org/index.php/2013/01/18/vladimir-nabokov-jamesmossman-interview/>.

Richardson, R. 1995. Emerson: The Mind on Fire. London: University of California Press.

Rutledge, D. S. 2011. Nabokov's Permanent Mystery: The Expression of Metaphysics in His Work. Jefferson: McFarland.

Sherry, N. 2004. The Life of Graham Greene. Vol. I., London: Penguin Books. 
Shields, D. 2003. Remote: Reflections on Life in the Shadow of Celebrity. London: The University of Wisconsin Press.

Sisson, B. J. 2014. The Real Life of Sebastian Knight. In Alexandrov, Vladimir E. The Garland Companion to Vladimir Nabokov. London and New York: Routledge, p. 633-643.

Stoltzfus, B. 2014. Magritte and Literature: Elective Affinities. Leuven: Leuven University Press.

Stuart, D. 1968. The Real Life of Sebastian Knight. Angles of Perception. In Modern Language Quarterly, Sept 1968, p. 312-328.

Sylvester, D. 2010. Magritte. New York: Harry N. Abrams.

Toffler, A. 1964. Playboy Interview: Vladimir Nabokov. January 1964. [Accessed 2015-0816]. Available at $<$ http://longform.org/stories/playboy-interview-vladimir-nabokov $>$.

Torczyner, H. 1979. Magritte. Ideas and Images. New York: Harry N. Abrams.

Vries de, G. - Johnson, D. B. 2006. Vladimir Nabokov and the Art of Painting. Amsterdam: Amsterdam University Press.

Waldnerová, J. 2008. De/Konštrukcia fikčných svetov. Nitra: Univerzita Konštantína Filozofa. Warburton, E. 2004. John Fowles - A Life in Two Worlds. Jonathan Cape: London.

Whitfield, S. 1992. Magritte. London: South Bank Centre.

Zlatoš, P. 2002. Artistic Mimesis and Pragmatics in the Morphology of the Work of Art. In Valentová, M. (ed.). Work of Art: From Reception to Morphology (Essays in Pragmatic Aesthetics). Nitra: Constantine the Philosopher University, p. 69-77.

Mária Kiššová

Department of English and American Studies

Faculty of Arts

Constantine the Philosopher University in Nitra

Štefánikova 67

94974 Nitra, Slovakia

mkissova@ukf.sk

\section{Acknowledgment}

This work was supported by a grant of the project VEGA: 1/0360/14: Osnovné tematické algoritmy v slovesnom umení (s intersemiotickými a interdisciplinárnymi presahmi) and UGA I-14-201-00 Aspekty literárnej recepcie a interpretácie v praxi II. 